\title{
America and the special relationship: the impact of the Trump administration on relations with the UK
}

\author{
Ruike $\mathrm{Xu}^{1} \cdot$ Wyn Rees $^{2}$
}

Accepted: 5 November 2021 / Published online: 30 November 2021

(c) The Author(s), under exclusive licence to Springer Nature Limited 2021

\begin{abstract}
The article seeks to assess to what extent the Trump presidency damaged the Anglo-American special relationship. By drawing on a theoretical framework that is broader than much of the existing literature, this article argues that the Trump presidency inflicted largely short-term damage on the special relationship. Though common interests, common sentiments and mutual utility between the US and the UK were weakened in the Trump era, the institutionalized underpinnings of the special relationship were sufficiently robust to withstand the corrosive effects of the 'Trump doctrine'. While President Biden cannot undo the negative impact of Brexit on the UK's utility to the US, the early period of his presidency has witnessed the special relationship's rapid recovery from most of the damage inflicted by the Trump presidency.
\end{abstract}

Keywords Special relationship · Trump doctrine $\cdot$ Global Britain · Brexit

\section{Introduction}

One of the notable features of the literature on the Anglo-American 'Special Relationship' is that it has been written predominantly from the perspective of the UK. A few authors have written about the US views of the relationship-such as Edelman, Burk and May and Treverton (Edelman, 2010; Burk, 2007; May and Treverton, 1986) — but the majority of literature has come from the UK side. This is unsurprising considering the relationship has been much more important for the UK than for

Wyn Rees

Wyn.Rees@nottingham.ac.uk

Ruike Xu

ruike.xu@bfsu.edu.cn

1 Beijing Foreign Studies University, Beijing, China

2 University of Nottingham, Nottingham, England, UK 
the US. It also reflects the fact that many countries around the world, other than just the UK, claim to enjoy an unusually close relationship with the US.

This article argues that it is a uniquely propitious moment to analyse the AngloAmerican relationship from the viewpoint of the US. By looking at the special relationship from the US perspective, this article focuses mainly on what the US expects from the UK in light of its global interests, how the US perceives its relationship with the UK in both utilitarian and sentimental terms, and why the US gets used to cooperating with the UK in the security and defence realm. Admittedly, the UK and the US have divergent expectations of the special relationship. For the UK, the special relationship helps to support its claim to be a major power with a global impact. As a result, for the UK, 'the special relationship tends to become an end in itself' (Danchev, 2016, p. 133). For the US, by contrast, the special relationship is about convenience. The UK's support is not indispensable for the US to advance its global interests, for example, in the Indo-Pacific region. The US expects the UK to be a useful and loyal ally whenever it needs support. As a result, American leaders are less sentimental than their British counterparts, and perceive the special relationship more in utilitarian terms. There are moments in the Anglo-American relationship when the UK can substantially contribute to US global interests but otherwise the relationship is underpinned by long-standing habits of cooperation in the intelligence, nuclear and military fields.

The Trump presidency inflicted unprecedented strains on relations with the UK: the White House pursued avowedly nationalistic and protectionist policies that inevitably caused friction with America's allies. While the special relationship has traditionally been constructed around a discourse of partnership, shared interests and elite-level friendship, the Trump era offers an opportunity to measure the relationship during a highly turbulent period. That the Trump administration has now been succeeded by the Biden administration, with its return to more mainstream US policies, provides the chance to measure the damage that was exacted to the AngloAmerican relationship. It makes it possible to reflect on the role that the UK has come to play in American foreign policy.

The article will assess the importance of the UK to US policy through a theoretical framework that has been expanded beyond what has traditionally been applied to the special relationship. It will be argued here that four factors, rather than the usual two, better explain the US's attitude towards the UK. In addition to the usual agenda of common interests and common sentiments, it adds the factors of mutual utility and institutionalization. The article then proceeds to analyse how Trump impacted each of these four factors.

The article argues that three out of the four aspects of the special relationship were weakened during Trump's presidency. First, both common interests and common sentiments were damaged as a result of Trump's policies. Second, mutual utility was diminished: partly the result of Brexit, which Trump had encouraged, and partly the implementation of the so-called 'Trump doctrine'. Third, institutionalization within the relationship proved to be resilient as routine cooperation in conventional, nuclear and intelligence matters continued unabated (Marsh, 2018, p. 273).

The last section of the article argues that the impact of the Biden administration is likely to be more varied than many have expected. Thus far, Biden has improved 
the sentimental facets of the relationship and, by re-committing the US to multilateral engagement, has diminished policy differences, and enhanced common interests between the two countries. On issues related to the liberal international order, China and Iranian nuclear non-proliferation, steps have been taken to repair divergences. But the utility of the UK to the US has not been transformed under Biden, not least because the UK - rather than the Trump administration - was the cause of its decline. Brexit has made the UK a less valuable partner to America across several policy domains and this will not be changed by a new presidential incumbent.

\section{Theorizing the special relationship}

Most British scholars of Anglo-American relations have explained the persistence of the special relationship by employing a framework of interests and sentiments. Where they have differed is over how much weight to assign to interests compared to sentiments, resulting in the explanatory divide between the school of sentiments (or evangelical school) and the school of interests (or functional school) (Danchev, 1996, pp. 738-740; Reiss, 2009, p. 2; Dobson and Marsh, 2014, p. 683). Other British scholars take a more eclectic approach and argue that both common interests and common sentiments have played indispensable roles in helping maintain the special relationship, albeit with the former being more important than the latter (Reynolds, 1986; Dobson, 1995, p. 167; Dumbrell, 2009, pp. 273-274).

Though they are important constitutive elements of the special relationship, common interests and common sentiments are inadequate explanations alone for the persistence of the special relationship. It is widely accepted that common interests provide the strongest motive for Anglo-American cooperation. As Gompert (2003, p. 44) rightly argues, 'the US-European relationship can be no stronger than the contemporary interests it serves'. The US-UK relationship is no exception. However, cooperative motives cannot automatically translate into close and endurable cooperation. The two countries are expected to be capable and credible allies to each other to sustain their long-term close cooperation.

To be a capable ally to each other means that there exists mutual utility between the two countries. Mutual utility describes to what extent the US and the UK are capable of assisting in securing each other's objectives (Dobson and Marsh, 2013, p. 3), and how the two countries are predisposed to advancing each other's interests. Scholars such as Danchev (1997, p. 752) and Wallace (2005, p. 55) argue that following the end of the Cold War, the diminishing utility of the UK to the US resulted in the fading of cooperative momentum in the special relationship. Only if the US regards the UK to possess the capability and the political will to act in its support can long-term cooperation be achieved. For example, the presence of the UK in a crucial forum such as the European Union (EU) provided valuable benefits to US administrations. These included the UK's desire to serve as a transatlantic bridge; its ability to obstruct policies deemed contrary to American interests and its access to intelligence sharing arrangements among EU member states. In the words of former Prime Minister David Cameron, the Anglo-American relationship has '...deliver(ed) for both of us' (Quoted in Dumbrell, 2013, p. 99). The US also appreciates the role 
the UK has played as a leading state within NATO, as a permanent member of the United Nations Security Council, as a Group of Seven (G7) member and as one of the world's leading economies. Furthermore, when conflicts erupted, the US could rely upon its ally to join American coalitions and make the second largest military effort.

To be a credible ally to each other means that there exists mutual trust between the two countries. Given shared kinship, culture and democratic values, there has existed a strong Anglo-American collective identity, resulting in common sentiments between the two countries (Hendershot and Marsh, 2020, p. 271). Common sentiments help to cultivate a high degree of mutual trust (Hoffman, 2002, p. 379). Common sentiments refer to mutual affection and favourable feelings between the US and the UK at both the leadership level and the public level. Nevertheless, common sentiments are not enough to explain the strong mutual trust between the two countries. The high level of institutionalization that exists should also be taken into account. While sentiments in Anglo-American relations fluctuate over periods of time, institutionalization proves to be a more stable factor in helping maintain strong mutual trust between these two allies.

Institutionalization can be defined as the presence of formal or informal rules or agreements, that create norms, routinize practices, and differentiate functions between actors (Keohane, 1988, p. 174; Walt, 1997, p. 166). It has led to regular patterns of consultation, practical collaboration and expectations of working together. Institutionalization has been at the heart of the special relationship, helping to explain the remarkable continuity in the fields of intelligence, nuclear and military cooperation. The UK intelligence and nuclear agencies have actively cultivated intimate relationships with their US counterparts and this has resulted in the sharing of information and practices. This reflex of cooperation and the inter-lacing of their security establishments has contributed to a deep-seated sense of trust and path dependency between the two sides (Ikenberry, 2001, pp. 16-17; Hopf, 2010, pp. 543).

This article contends that it is necessary to broaden the theoretical framework of the special relationship to add mutual utility and institutionalization to provide a more comprehensive understanding of its persistence. Common interests, common sentiments, mutual utility and high-level institutionalization, reinforce each other to give the relationship its durability. This article will now look at each aspect of the special relationship in detail to measure how they were impacted during the Trump era. In the final section, there is an assessment of how the early period of the Biden administration has altered the legacy of the Trump administration.

\section{Anglo-American common interests under Trump}

Since the end of World War II, upholding the liberal international order and working in unison against their gravest and most common threats have been the two fundamental and overarching common interests that bind the US and the UK together (The US Congress, 2019). Before January 2017, when Trump assumed the presidency, successive American administrations had, in large measure, managed to work 
together with their British counterparts to uphold the liberal international order, and to maintain a consensus over the threat from Soviet communism in the Cold War and Islamist terrorism after 9/11. The Trump presidency, however, threw that consensus into disarray. He was the first post-war American president who was actively hostile to liberal internationalism and appeared to question the entire idea of the liberal international order (Ikenberry, 2019, pp. 10-11). By actively seeking to dismanthe the liberal international order that America had played a leading role in creating, Trump dealt a heavy blow to the foundational worldview of the special relationship (Ikenberry, 2018, p. 7; Kaufman, 2017, p. 251).

Trump enlarged the policy gap with America's allies and exacerbated the differences through his abrasive personal style. The so-called 'Trump doctrine' eroded the common interests that had hitherto existed with the UK. The president was 'contemptuous of almost all the institutions that make up the liberal international order' (Mearsheimer, 2019, p. 29), insisting that it imposed disproportionate costs on the US (Brands, 2018, p. 163). Trump demonstrated this by reneging on multilateralism. He was critical of key organizations, like NATO, the G7 and the World Trade Organization (WTO) (Kaufman, 2017, p. 251).

The US even went so far as to withdraw from a battery of such organizations and agreements, the most prominent of which included the Trans-Pacific Partnership (TPP), the Paris agreement on climate change, the Joint Comprehensive Plan of Action (JCPOA, commonly known as the Iran nuclear deal), the United Nations Educational, Scientific, and Cultural Organization (UNESCO), and the UN Human Rights Council (UNHRC).

The May and Johnson governments have advocated the concept of 'Global Britain', refuting that Brexit would herald a diminution of the UK's international engagement. Yet Global Britain was incompatible with the Trump doctrine. Global Britain could only thrive on the continuing existence of the liberal international order and Trump made clear his rejection of the key elements of that order (Nye, 2019, pp. 71-72; Chalmers, 2019, pp. 3-4). The UK wanted to preserve and enhance its international standing by engaging in multilateral frameworks. In contrast to the Trump administration's withdrawal from the TPP, the British government tried to join its successor, the Comprehensive and Progressive Agreement for Trans-Pacific Partnership (CPTPP). The UK continued to prioritize the Paris agreement and the government of Boris Johnson undertook to host the 26th UN Climate Change Conference of the Parties (COP26) in November 2021 in Glasgow, the most significant UN climate summit since the Paris agreement was concluded in 2015 (The UK Government, 2020a). In addition, the UK did not follow the US in threatening to withdraw from the WTO and the World Health Organization (WHO). At the perilous time of the global coronavirus pandemic, Johnson distanced the UK from the Trump administration by providing generous financial support to the WHO (WHO, 2021).

The JCPOA proved to be one of the most serious bones of contention, creating constant strains in the relationship between the US and the UK. Trump chose to disregard the UK efforts to diminish the extent of the policy difference and pressed London to shift towards the US position, threatening to withhold benefits and even punish the UK if it did not comply. For example, a senior Trump official warned Johnson in January 2020 that the prospect of a UK free trade deal with the US was 
at risk unless he pulled out of the JCPOA (Wintour, 2020). Despite such pressure and threats, both the May and Johnson governments declined to follow Trump's policy on Iran. They feared an American policy that risked wider conflict in the region, undermined the presence of western forces and edged Iran towards a nuclear bomb. The UK pushed back by working with other permanent members of the UN Security Council plus Germany (P5+1) to prevent the JCPOA from collapsing and preserve the trade in non-sanctioned goods. In a statement on 12 January 2020, Johnson sided with Chancellor Merkel and President Macron to reaffirm the Iran nuclear deal. The foreign ministers of the UK, France and Germany went on to trigger a formal dispute mechanism to attempt to get Iran to abide by the terms of the agreement (The UK Government, 2020b).

For most of the Trump presidency, the US and the UK differed over what constituted their gravest threats. While the Trump administration identified China as the gravest threat to American security and pre-eminence, the May government and the first year of the Johnson government considered China more of an opportunity than a threat to the post-Brexit UK. The UK did not echo Washington's concerns about China's Belt and Road initiative (BRI) and chose to participate in the Asian Infrastructure Investment Bank (AIIB), despite warnings from the US. In her first article in a newspaper since resigning from the premiership in June 2019, Theresa May (2020) continued to argue that the UK's special relationship with the US should not prevent it from working with China.

Trump chose a confrontational policy with China that diverged from the UK position. Building on President Obama's 'pivot' towards Asia, Trump reversed a decades-long strategy of seeking to deepen engagement with Beijing (The White House, 2020) and shifted to imposing a series of trade tariffs and protectionist policies. He threatened to retaliate against western countries that did not follow America's lead, with obvious implications for the UK. Armed with so-called 'principled realism', the White House focussed its attention on the great-power competition with China (Colby and Mitchell, 2020). This placed the UK in a difficult position. While sharing concerns over China's security clampdown in Hong Kong and its military measures in the South China Sea, neither May nor Johnson was willing to follow the president's approach. For them, “....it remains in UK interests to resist US pressure to view all relations with China as part of a zero-sum competition for dominance" (Chalmers and Jessett, 2020, p. 8).

The UK's divergence from the US stance was best evidenced by its attitude towards the multinational company Huawei and its participation in the country's fifth-generation digital network (5G) (Summers, 2020, p. 173). May defied the US by giving Huawei limited access to non-core parts of the UK 5G network. Johnson faced increasing pressure from the Trump administration to reverse this policy, even threatening to restrict intelligence sharing with the UK (Shipman, 2020). The UK announced in January 2020 that it was designating Huawei as a high-risk vendor, allowing the company to have only a limited role in building non-core parts of the $5 \mathrm{G}$ network. Huawei was to be excluded from all safety and security aspects of Critical National Infrastructure and limited to a minority presence in other network functions up to 35\% (Raab, 2020). Further action by the US against Huawei led the UK's National Cyber Security Centre to advise the government to ban mobile phone 
providers from using Huawei equipment by the end of 2020 and remove all of the company's equipment from networks within seven years (The UK Government, 2020c). The Trump administration sought to pressure the UK into acceding to its China policy and worked with a group of Conservative backbenchers, led by Sir Ian Duncan-Smith, who were hostile to any form of technological dependency on Chinese firms. Thus, the Johnson government's final decision to ban Huawei won applause from the Trump administration (Biegun, 2020).

\section{Common sentiments in Anglo-American relations under Trump}

Common sentiments, at both the elite and the public level, have been an integral part of US-UK relations. The Trump presidency, however, tested the strength of those sentiments. Wright (2019) argues that the Trump era marked the lowest ebb of the special relationship since the 1956 Suez Crisis.

At the elite level, Trump retained the rhetoric of sentimentality. In every joint press conference with Theresa May, he reaffirmed the relationship's distinctiveness and declared it to reside in 'common history, values, customs, culture, language, and laws' (The White House, 2019). He remained consistent with earlier US presidents who had publicly affirmed the existence of a privileged and intimate relationship between the two countries. Yet in his behaviour Trump demonstrated a disdain for any sentimental attachment to the UK. This should have come as no surprise, after all the president proclaimed himself a deal-maker and made no secret of his preference for a transactional approach to foreign policy. As Kagan remarked, 'Trump's policies are pure realism, devoid of ideals and sentiment, pursuing a narrow "national interest" defined strictly in terms of dollars and cents...' (Kagan, 2018).

Both Prime Ministers May and Johnson found it hard to establish a harmonious relationship with the president, given his mercurial personality and anti-internationalist and impulsive foreign policy. The personal chemistry between May and Trump was always poor, and he repeatedly displayed his low regard for her. Whereas British criticisms of American policy have always been conducted sotto voce, Trump did not refrain from publicly humiliating May, as exemplified by his personal attack on her over his retweeting of three anti-Muslim videos posted by the extremist group Britain First (Burns, 2018). Trump also poured scorn on May for failing to follow his advice on strategy towards Brexit (Bolton, 2020). He had proffered advice to her during an earlier visit at Chequers, but her failure to take a negotiated Brexit deal through the House of Commons three times led the president to ridicule her approach and welcome her replacement. It was an insight into both the president's personality and the deep inequality in the relationship between the two countries. Though superficially maintaining a better personal relationship with Trump, Johnson was wary of being seen as close to the president. Rather than taking it as a compliment, he felt embarrassed by Trump's public comment that he was 'Britain's Trump'. Apart from embracing populism as a vehicle to deliver Brexit, Johnson had few similarities with Trump in terms of political outlook on domestic and foreign affairs. Unlike the president, Johnson was committed to the idea of democracy at home and the liberal international order abroad. He publicly condemned Trump for 
inciting people to storm the Capitol and for casting doubt on the outcome of the 2020 presidential election (BBC, 2021).

The poor level of US-UK sentimental attachment was exemplified by the Darroch affair in which the personal communications of the British ambassador in Washington were leaked to the press, presumably by hostile interests within the Conservative Party. In these communications, Sir Kim Darroch described the Trump administration as 'inept' and 'uniquely dysfunctional' and the president as a deeply 'insecure' personality. The revelations were highly embarrassing and the president responded by refusing to have any further dealings with the ambassador. Darroch resigned in July 2019 and the UK government experienced the humiliation of removing its ambassador. Darroch was only the third British ambassador in history to become persona non grata in Washington (Reynolds, 2019).

At the popular level, the American people's sentimental attachment to the UK remained remarkably strong during the Trump presidency. According to polling data by Gallup between 2017 and 2020, the UK was consistently the second most favourable country of the American people, only trailing behind Canada (Gallup, 2021). However, the Trump era witnessed a drop in the popularity of the US among the British public. According to polling data by the Pew Research Centre, the proportion of the British people holding a favourable view of the US in 2017 and 2019 were $50 \%$ and $57 \%$, respectively, a historic low over the past decade. In the same surveys, the British people's favourable view of the American president also hit a historical low: $22 \%$ in 2017 and $32 \%$ in 2019. Trump's controversial leadership style in domestic and foreign affairs largely accounted for this low popularity. In domestic affairs, he frequently failed to uphold democratic principles and human rights, as exemplified by his controversial immigration policies, such as the Muslim travel ban and family separation policy. In foreign affairs, Trump weakened American strategic credibility as a responsible and benign hegemon in the eyes of the UK.

\section{Anglo-American mutual utility under Trump}

Brexit has weakened the UK's utility to the US in economic, diplomatic and security terms (Wilson, 2017, p. 555). However, its negative impact should not be exaggerated. The shift in strategic emphasis by the US from the Euro-Atlantic to the IndoPacific region has exerted a more far-reaching impact on its perception of the UK's value as an ally. This section will focus on the extent to which the UK's utility to the US in diplomatic and security terms has been weakened since 2017.

Trump's attitude towards the utility of the UK was telling. He preferred to deal with both allies and adversaries 'on the basis of cost-benefit calculations as to how each relationship works in America's perceived economic or political interests' (Stokes, 2018, p. 137). In Trump's mindset, utility and reciprocity far outweighed the importance of sentimental attachment. Although the president encouraged the UK's departure from the EU, he was fully aware that Brexit diminished the UK's diplomatic and security utility to the US (Stephens, 2021). Following the 2016 referendum, the UK could no longer make full use of its membership to play the role 
of a loyal ally to the US in representing and promoting American security and diplomatic interests within Europe.

Trump made no secret of his dislike of the EU. He castigated it as America's 'foe' and complained that the EU's position on trade was "worse than China", and initiated tariff barriers against some of its goods, such as steel, aluminium and automobiles. What disappointed the president was that both the May and Johnson governments sided with other EU members against the Trump administration's punitive tariffs on EU goods (Sillars, 2019). The UK's diplomatic utility on the issue of the JCPOA also dwindled. Instead of playing an effective interlocutor role to help the Trump administration persuade the EU to support its stance, both the May and the Johnson governments worked together with their EU counterparts in trying to save the JCPOA.

In regards to European defence, the Trump administration could no longer rely upon the UK as a brake on military initiatives that impinged on NATO's primacy. The UK had forfeited decision-making rights over the EU's Common Security and Defence Policy (CSDP), as well as the ability to exercise command responsibility for CSDP missions and EU battlegroups (Mills and Smith, 2021, p. 4). What unsettled the Trump administration was the rapid progress of the EU on CSDP, as evidenced by the establishment of a host of new defence institutions, such as the Military Planning and Conduct Capability (MPCC), Permanent Structured Cooperation (PESCO), the Co-ordinated Annual Review of Defence (CARD) and the European Defence Fund (EDF) (Mills, 2019, pp. 3-4). The post-Brexit UK could do little to alleviate the Trump administration's growing concerns over the protectionist tendency of the EU's new defence institutions (Emmott, 2019).

Nevertheless, as a committed NATO member, the UK continued to be a valuable military ally for the US in the Euro-Atlantic region. President Trump lauded the UK's commitment to meeting NATO's $2 \%$ spending target, and he won the support of both May and Johnson in urging other European countries to raise defence spending. The UK was also the most ardent ally of the US in imposing and maintaining sanctions against Russia.

The UK is a less useful ally to the US in the Indo-Pacific than in the Euro-Atlantic region. The UK is not on the Pacific Rim and has fewer geopolitical advantages and strategic assets than other US partners. The US had shifted its attention away from Europe to the Indo-Pacific before the Trump Presidency: he only accelerated the trend (Martill and Sus, 2018, p. 849). For the Trump administration, Japan, Australia and India were the Tier 1 partners with more diplomatic and security utility than the UK in helping to push forward its Indo-Pacific strategy. The UK, by contrast, has struggled to be at the forefront of the US's Tier 2 partners in the region.

Given that the Indo-Pacific region has become a new geopolitical centre of gravity in recent years, both the May and Johnson governments have sought to increase the UK's standing there. Only through possessing the capability to project power and play a significant role in the Indo-Pacific region can the post-Brexit UK become a serious global player that could reinvigorate its special relationship with the US in the era of great-power competition. Otherwise, the special relationship could not reverse its long-term downward trend. 
Brexit preoccupied the attention of the May government and the first year of the Johnson government and distracted the UK from enhancing its role in the region. The May and Johnson governments did devote efforts to improving the UK's security ties with Japan through regular defence dialogues and joint exercises (Hornung, 2020, p. 35). However, Japan regarded France, rather than the UK, as its favourite partner in security and political terms even though prior to 2016, it had treated the UK as its leading strategic partner in Europe (Tsuruoka, 2018, p. 3). In a similar vein, the UK was outcompeted by France in terms of security cooperation with India. In the eyes of the Modi government, the post-Brexit UK had a minimal strategic impact in the Indo-Pacific region; only France was seen as a major player because of its territorial and military presence in the Indian Ocean (Campanella and Dassù, 2019, p. 125). Also, the May government and the first year of the Johnson government demonstrated little value to the Trump administration in confronting China, except that the UK held several joint military exercises with the US in the South China Sea. By contrast, in response to China's growing challenge to maritime security, France successfully orchestrated a new strategic alliance with India and Australia in May 2018, entitled the Paris-Delhi-Canberra axis, and held their first ministerial-level meeting in September 2020 (Pajon, 2018, p. 4; India Ministry of External Affairs, 2020). As a result, France enhanced its standing in the Indo-Pacific region and boosted its utility to the US.

\section{The institutionalized Anglo-American security relationship under Trump}

It is the security relationship, conducted at the level of diplomats, military officials and intelligence officers that has been the heart of the day-to-day Anglo-American special relationship and provided much of its substance (Baylis and Wirtz, 2012: 260). This has become institutionalized over a long period of time and serves as the ballast or 'sub-structure' within the relationship (Wallace and Phillips, 2009, p. 263), insulating it from the vicissitudes of politics between Downing Street and the White House. Regular forms of interaction, constantly reproduced, have helped to shape cooperation, both proactively and in terms of constraining behaviour that would otherwise damage the relationship (Sanders, 2006, p. 42). Intelligence sharing and nuclear and military cooperation were least impacted by the Trump doctrine. Indeed, due to high-level institutionalization, continuity has been the hallmark of these aspects of the relationship throughout the period. It is unsurprising that the institutionalized security cooperation between the US and the UK continues to flourish under Biden because it never weakened during Trump's incumbency.

As the jewel in the crown of intelligence relations, the sharing between the UK Government Communications Headquarters (GCHQ) and the US National Security Agency (NSA) in signals intelligence has remained robust within the mechanism of the Five Eyes alliance, underpinned by the UK-USA Agreement (Aldrich, 2010). GCHQ and the NSA's cooperative relationship in dealing with cybersecurity threats flourished during the Trump administration. 
In March 2018, the heads of GCHQ, the NSA, the UK's Joint Forces Command and the US Cyber Command held a strategic review meeting in the US, and for the first time in history they issued a joint statement affirming Anglo-American unity (GCHQ, 2018). In the same month, the US demonstrated its solidarity with the UK intelligence community by helping to organize the largest expulsion of Russian spies in recent history (Mitchell, 2018). This was in response to Russia's alleged use of a nerve agent, Novichok, to poison a former spy living in Salisbury. What demonstrated the two countries' intention to further cooperate against cybersecurity threats was the NSA's establishment of the new Cybersecurity Directorate in July 2019, that followed the model of GCHQ's National Cyber Security Centre (The NSA, 2021a). GCHQ and the NSA strengthened their bonds against Russian cyber attacks, as highlighted by their joint efforts against the Turla group activity and the Russian military intelligence service, the GRU, intrusion set known as 'Sandworm' (NCSC, 2019, 2020).

The US-UK nuclear relationship has also sustained its cooperative momentum since 2017. The Trump administration made clear its continuing willingness to share the most sensitive nuclear technologies with the UK, a measure of the mutual trust between them. On 26 June 2018, defence officials from the two countries celebrated the 60th anniversary of the UK-US Mutual Defence Agreement (MDA) at the headquarters of the American Department of Energy (The US Department of Energy, 2019). The MDA was renewed in 2014 for another decade. The special nuclear relationship was buttressed further by the British Parliament's approval, in July 2016, for $£ 31$ billion, plus a $£ 10$ billion contingency fund, to be spent on building four replacement submarines to maintain the Trident II (D5) system.

In the Trump era, the institutionalized conventional military relationship maintained its specialness through concerted military actions, regular joint training exercises, and extensive and routinized personnel exchange programmes, underpinned by more than 20 embedded agreements (The UK Government, 2015). While the military draw-down in Afghanistan and Iraq reduced the intensity of cooperation, the habits of consultation endured. Upon the request of the Trump administration, the UK increased the number of its troops in both Afghanistan and Syria. The UK worked in unison with the US and France to launch missile strikes against Syria in April 2018 (Borger and Beaumont, 2018) and against Islamic State targets as part of Operation Shader. The UK and the US also conducted their first joint drills in the South China Sea in January 2019, openly challenging China's growing control in this area.

\section{A new era under Biden?}

With President Biden taking office in January 2021, the special relationship has entered a new chapter. Compared with the period of the Trump era, the special relationship has returned to a period characterized by greater predictability and adherence to multilateralism. The four factors that bind the special relationship together, common interests, common sentiments, mutual utility and institutionalization, will be areas in which both the Biden administration and the British government invest 
effort. There is already evidence in the short period of time in which President Biden has been in office that the policies of his predecessor are being abandoned.

In relation to interests and threats, President Biden has declared that the 'US is back' and has re-committed the US to proactively reshaping the liberal international order. In so doing he has removed one of the biggest stumbling blocks for the special relationship. The US and the UK are no longer at loggerheads in strategic orientation: Biden has realigned their interests in the face of the challenge by authoritarian states. Moreover, given the Biden administration's decision to revitalize America's network of alliances and partnerships, Anglo-American cooperation is more likely in dealing with global challenges (The US Congress, 2021a).

By re-emphasizing multilateralism in global affairs, the Biden administration's interests are more in harmony with those of the UK government when dealing with thorny global issues, such as climate change and the Covid-19 pandemic. Biden has returned the US to the Paris agreement, halted its withdrawal from the WHO and revitalized the WTO. He has adopted a firm approach towards Russia, reassuring the UK and European allies that they can depend upon America's commitment to NATO. Furthermore, the president has made efforts, through talks in Vienna, to restore the JCPOA, although he now faces a more hardline regime in Tehran under the direction of President Ebrahim Raisi (The US Senate Committee on Foreign Relations, 2021). What is now different is that the direction of travel of the Biden administration and Europe have been restored to alignment.

Where President Biden has not departed from President Trump's agenda has been in relation to China. In line with his predecessor, Biden's team has labelled China as the 'most serious competitor' (The White House, 2021) and the 'biggest geopolitical test of the twenty-first century' (Blinken, 2021). Biden has preserved many of the sanctions imposed on China under Trump and has maintained pressure on technology companies like Huawei. The Johnson government has followed this lead and officially designated China as 'a systemic competitor' and 'the biggest state-based threat to the UK's economic security' (The UK Government, 2021).

The Biden administration has continued to prioritize the Indo-Pacific region. The White House has responded to signals from London about its desire to play a more significant role by attaching weight to the utility of the UK in its diplomatic and security contribution towards managing China. In its Integrated Review of Security, Defence, Foreign Policy and Development, the Johnson government signalled its own pivot towards the Indo-Pacific region (The UK Government, 2021). US competition with China is unfolding on multiple fronts. Both the Biden administration and the UK government are seeking to reduce dependence on Chinese supply chains for strategically critical goods, while refraining from a full-scale decoupling from the Chinese economy. As a leading techno-democracy ranked fourth in the Global Innovation Index (2020), the UK is capable of helping the US to strengthen its advantage in the increasingly fierce technological rivalry with China.

As regards common sentiment at the elite level, Biden has never made a secret of the fact that he values the US's special relationship with the UK, asserting that the two countries have been locked cheek to jowl on almost every important issue (Biden, 2018, p. 6). While Biden has little sentimental attachment to Prime Minister Johnson, there has been no difficulty in forging a cooperative relationship 
between the two governments. Within the first few months of the Biden presidency, the elite-level relationship returned to normal. The only source of irritation, given his Irish heritage, was Biden's concern over the impact of Brexit on the peace process in Northern Ireland. The US Congress has stated that the US would not entertain any future economic agreements with the UK if peace in Northern Ireland was undermined (House Foreign Affairs Committee, 2020; The US Congress, 2021b). The Biden administration has sought to orchestrate a global democratic coalition to defend and reshape the liberal international system. The UK has been able to step forward as the US's most reliable and committed ally. President Biden's initiative of a Summit of Democracies dovetails with Prime Minister Johnson's proposal of a D10 grouping of the major democracies. By inviting Australia, India and South Korea to attend the G7 summit in June 2021, the UK was able to facilitate a global coalition of democracies.

To complement the improvement in elite-level sentiment, there has been an improvement in popular attitudes between the two countries since the 2020 presidential election. According to polling data by Gallup in February 2021, the UK remained the second most favourable country for the American people, and $91 \%$ of Americans had positive views of the UK. The British hostility towards the American presidency has also dissipated. The Pew Research Centre survey of 19 January 2021, reported that $65 \%$ of the British had confidence in Biden to do the right thing in world affairs, an increase of $24 \%$ in comparison to the low rating Trump received in 2020 (Pew Research Centre 2021).

The issue of mutual utility for the Biden administration has been impacted by Brexit: without EU membership the UK is an ally of diminished utility. President Biden was a critic of Brexit and his own priority has been to restore America's relations with the EU that were damaged by his predecessor. In fulfilling that objective, President Biden has regarded France and Germany as of greater utility in Europe than the UK because of their ability to shape EU policy.

Given the Johnson government's decision to increase defence spending by $£ 16.5$ billon between 2020-2021 and 2024-2025, the UK has taken steps to increase its military utility to the US (The UK Government, 2021). This was an area in which former US administrations had berated the UK, especially over the swinging cuts that were imposed in the UK defence reviews of 2010 and 2015. Having left the EU, the UK has re-emphasized the central role it wants to play within NATO and it will continue to be the most capable Alliance member in Europe, sharing the security burden with the US.

On the diplomatic front, the two sides have worked in unison to challenge China's stance on human rights issues related to Xinjiang and the US has appreciated the leadership that the UK has provided on visas for Hong Kong residents seeking to leave the territory. Together with the EU countries and Canada, the US and the UK are united in imposing sanctions on Chinese officials over the 'reeducation' camps for Uighurs. They have both taken concerted diplomatic moves at various times, either with other members of the 'Five Eyes' community or G7, to exert political pressure on the Chinese government over issues related to the democracy of Hong Kong since May 2020. 
As regards security, there is a limit to the UK's capacity to contribute meaningfully to defence efforts in the Indo-Pacific region. The US will have to look principally to members of the Quadrilateral Security Dialogue or 'Quad'-Japan, Australia and India - to partner it in standing up to China's power in the region. However, there is a security contribution that the UK can make. With the availability of the joint Anglo-American Carrier Strike Group, led by HMS Queen Elizabeth, the Johnson government can increase its security utility to the Biden administration by participating in 'freedom of navigation' patrols. The UK indicated its desire to be more involved through a security pact with the US and Australia, to be known as AUKUS. At the heart of the arrangement is a plan to build eight Australian nuclearpowered submarines that will be based on either the US Virginia class or British Astute class hunter killer vessels (The Economist, 2021, p. 21).

Moreover, the UK can be a capable ally with utility for the US in coping with China's threats in space and cyberspace. The two countries signed the US-UK Technology Safeguards Agreement in June 2020, enabling American companies to launch rockets from British soil for the first time. To keep abreast of the US's move to set up a space force and a space command, the Johnson government announced the creation of the UK's Space Command in November 2020 and appointed Paul Godfrey as its first commander in February 2021. Paul Godfrey was formerly in charge of the planning and employment of coalition air and space power across the Middle East within the US Air Force Combined Air and Space Operations Centre between 2017 and 2020. By setting up a National Cyber Force in November 2020, the UK is better positioned to strengthen its cooperation with the US Cyber Command in offensive cyber actions against their common rivals.

The final aspect of the relationship is its institutional dimension and it has been an important component of President Biden's first year in office. Anglo-American nuclear cooperation has endured, underpinned by the MDA and the Polaris Sales Agreement. The US treats the UK as its closest nuclear partner and continues to exchange nuclear secrets, share its submarine delivery system, and cooperate against nuclear terrorism. Nuclear cooperation with the US will reach a new high if the Biden administration decides to work with the UK on a joint project in developing the W93 nuclear warhead (The US Congress, 2021c).

The NSA and GCHQ have expanded their institutionalized cooperative relationship in cyberspace. On 5 March 2021, they celebrated the 75th anniversary of the formalized agreement entitled the BRUSA Agreement (renamed as the UK-USA Agreement in 1955), enabling personnel of the NSA and GCHQ to work together as an integrated community to address threats across all domains (The NSA, 2021b). The future trend for cooperation between the two agencies will be their increasing dependence on artificial intelligence to cope with their shared cybersecurity threats.

The institutionalized conventional military cooperation under Biden has provided a mixed picture. The precipitate withdrawal of US forces from Afghanistan in the summer of 2021 caused considerable tensions between London and Washington and strained the British resolve to make only criticisms in private. The British military felt that an unwise policy had resulted in the collapse of the western position in the country. This difficult episode was counter-balanced, to a limited extent, by the Joint Declaration for the Carrier Strike Group 2021 (The US Department of Defense, 
2021) under which US aircraft and a destroyer accompanied the Royal Navy's aircraft carrier HMS Queen Elizabeth on its maiden operational deployment to the Indo-Pacific region in May 2021.

\section{Conclusion}

President Trump's foreign policy called into question long-standing alliances and disengaged the US from a range of multilateral institutions. The Anglo-American special relationship was subjected to considerable strains during this period, including over common interests and sentimental linkages. Trump was dissatisfied that the UK was reluctant to follow America's lead in withdrawing from the JCPOA and confronting China. But it was in the area of mutual utility that the most lasting damage was done and Trump does not deserve all of the blame because Brexit was only a policy that he encouraged, but did not instigate.

For the Biden administration, the post-Brexit UK is a diminished ally, less able to perform the role of America's strategic partner in an age of growing great-power competition. Without the support of the EU behind it, the UK will be forced to work harder to realize its vision of a 'Global Britain' wielding influence abroad and it will be more vulnerable to American demands in shaping a trade deal. In order to enhance its value to the US, the UK has initiated a pivot towards the Indo-Pacific region that will prove challenging to resource.

During the Trump administration, the underlying institutional relationship between the two countries remained cohesive. In matters of intelligence cooperation, in sharing counter-terrorism information, in day-to-day contacts between the US-UK armed services and in nuclear collaboration, the institutional relationship continued unabated. This illustrated the fact that it is insulated from the tensions of the elite-level relationship. However, the institutional relationship cannot carry the weight of the special relationship for long. If efforts are not made at the level of political elites to realign common interests, if the gap is allowed to widen, then even institutional links between officials and military officers will suffer and begin to degrade. If the US comes to view the UK as no longer its partner of choice, then the institutional sinews of the relationship will be at risk of atrophying.

The speed with which President Biden has been able to restore key aspects of the special relationship confirm that Trump's impact was largely short term. Although not all of Trump's legacy will be over-turned, many of the points of friction with the UK, such as over Iran and the conduct of inter-personal relationships, have been rectified and resumed their former character. The Anglo-American relationship remains unequal, but it still has value to a US administration, whatever its political hue.

\section{References}

Aldrich, R. 2010. GCHQ. New York: Harper Collins.

Baylis, J., and J. Wirtz. 2012. The U.S.-UK "Special Military Relationship": Resetting the partnership. Comparative Strategy 31 (3): 253-262. 
BBC. 2021. Capitol riots: Boris Johnson condemns Donald Trump for sparking events, 7 January. Retrieved April 30, 2020, from https:/www.bbc.com/news/uk-politics-55580806.

Biden, J. 2018. A vision for the future of the transatlantic relationship. Speech at Chatham House, 10 October. Retrieved December 4, 2019, fromhttps://chathamhouse.soutron.net/Portal/DownloadIm ageFile.ashx?objectId=1733.

Biegun, S.E. 2020. Written Testimony of Deputy Secretary of State Stephen E. Biegun, U.S. Policy Toward China, United States Senate Committee on Foreign Relations, 22 July. Retrieved October 30, 2020, from https://www.foreign.senate.gov/imo/media/doc/072220_Biegun_Testimony.pdf.

Blinken, A. 2021 A Foreign Policy for the American People, 3 March. Retrieved April 30, 2021 from https://www.state.gov/a-foreign-policy-for-the-american-people/.

Bolton, J. 2020. The room where it happened: A white house memoire. New York: Simon \& Schuster.

Borger, J. and Beaumont, P. 2018. Syria: US, UK and France launch strikes in response to chemical attack, The Guardian, 14 April. Retrieved December 16, 2019, from https://www.theguardian.com/ world/2018/apr/14/syria-air-strikes-us-uk-and-france-launch-attack-on-assad-regime.

Brands, H. 2018. American grand strategy in the age of Trump. Washington: Brookings Institution Press.

Burk, K. 2007. Old world, new world: Great Britain and America from the beginning. New York: Atlantic Monthly Press.

Burns, N. 2018. Testimony to the Senate Foreign Relations Committee, Assessing the Value of the NATO Alliance, Ambassador (ret.) Nicholas Burns, 5 September. Retrieved October 30, 2021, from https:// www.foreign.senate.gov/imo/media/doc/090518_Burns_Testimony.pdf.

Campanella, E., and M. Dassù. 2019. Anglo Nostalgia: The politics of emotion in a fractured west. London: Hurst \& Company.

Chalmers, M. 2019. Which rules? Why there is no single 'Rule-Based International System', RUSI Occasional Paper. Retrieved December 18, 2019, from https://rusi.org/sites/default/files/201905_op_ which_rules_why_there_is_no_single_rules_based_international_system_web.pdf.

Chalmers, M. and Jessett, W. 2020. Defence and the integrated review: A testing time, RUSI Whitehall Report 2-20, March: 1-15.

Colby, E. and Mitchell, A. 2020. The age of great-power competition, Foreign Affairs, January/February. Retrieved June 3, 2020, from https://www.foreignaffairs.com/articles/2019-12-10/age-great-powercompetition.

Danchev, A. 1996. On specialness. International Affairs 72 (4): 737-750.

Danchev, A. 1997. On friendship: Anglo-America at Fin De Siècle. International Affairs 73 (4): 747-759.

Danchev, A. 2016. On good and evil and the grey zone. Edinburgh: Edinburgh University Press.

Dobson, A. 1995. Anglo-American relations in the twentieth century: Offriendship, conflict and the rise and decline of superpowers. London: Routledge.

Dobson, A., and S. Marsh. 2013. Introduction. In Anglo-American relations: Contemporary perspectives, ed. A. Dobson and S. Marsh, 1-25. London: Routledge.

Dobson, A., and S. Marsh. 2014. Anglo-American relations: End of a special relationship. The International History Review 36 (4): 673-697.

Dumbrell, J. 2009. US-UK relations: Structure, agency and the special relationship. In The Blair legacy: Politics, policy, governance and foreign affairs, ed. T. Casey, 273-284. London: Palgrave Macmillan.

Dumbrell, J. 2013. Personal diplomacy: Relations between prime ministers and presidents. In AngloAmerican relations: Contemporary perspectives, ed. A. Dobson and S. Marsh, 82-105. London: Routledge.

Edelman, E. 2010. A special relationship in jeopardy, The American Interest, July-August, 25-34.

Emmott, R. 2019. "Poison pills": Pentagon tells EU not to block U.S. companies from defense pact. Reuters, 14 May. Retrieved May 1, 2021, from https://www.reuters.com/article/us-usa-eu-defenceidUSKCN1SK1V9.

Gallup. 2021. Country ratings. Retrieved June 5, 2021, from https://news.gallup.com/poll/1624/perce ptions-foreign-countries.aspx.

GCHQ. 2018. The national security agency-An enduring and vital partnership, 26 March. Retrieved December 29, 2019, from https://www.gchq.gov.uk/news-article/joint-statement.

Gompert, D. 2003. What does America want of Europe? In Shift or rift: Assessing US-EU relations after Iraq, ed. G. Lindstrom, 43-73. Paris: Institute for Security Studies.

Hendershot, R., and S. Marsh. 2020. Culture matters: Anglo-American relations and the intangibles of 'specialness.' Manchester: Manchester University Press. 
Hoffman, A. 2002. A conceptualization of trust in international relations. European Journal of International Relations 8 (3): 375-401.

Hopf, T. 2010. The logic of habit in international relations. European Journal of International Relations 16 (4): 539-561.

Hornung, J.W. 2020. Allies growing closer: Japan-Europe ties in the age of strategic competition, Rand Report: 1-119.

House Foreign Affairs Committee. 2020. Engel statement on Brexit agreement between the United Kingdom and European Union, 26 December. Retrieved October 30, 2021, from https://foreignaffairs. house.gov/press-releases?ContentRecord_id=26CC720B-681A-4CE7-BE54-76F61EF53DDB.

Ikenberry, J. 2001. After victory: Institutions, strategic restraint, and the rebuilding of order after major wars. Princeton: Princeton University Press.

Ikenberry, J. 2018. The end of liberal international order. International Affairs 94 (1): 7-23.

Ikenberry, J. 2019. Reflections on after victory. British Journal of Politics and International Relations 21 (1): 5-19.

India Ministry of External Affairs. 2020. India-France-Australia joint statement on the occasion of the trilateral ministerial dialogue, 4 May. Retrieved October 31, 2021, from https://www.mea.gov.in/ bilateral-documents.htm?dt1/33845/IndiaFranceAustralia_Joint_Statement_on_the_occasion_of_ the_Trilateral_Ministerial_Dialogue_May_04_2021.

Kagan, R. 2018. Trump's America does not care, The Washington Post, 14 June. Retrieved December 13, 2019, from https:/www.washingtonpost.com/opinions/donald-trumps-america-the-rogue-super power/2018/06/14/c01bb540-6ff7-11e8-afd5-778aca903bbe_story.html.

Kaufman, J. 2017. The US perspective on NATO under Trump: Lessons of the past and prospects. International Affairs 93 (2): 251-266.

Keohane, R. 1988. Alliances, threats and the use of neorealism. International Security 13 (1): 169-176.

Marsh, S. 2018. The US, BREXIT and Anglo-American Relations. Journal of Transatlantic Studies 16 (3): 272-294.

Martill, B., and M. Sus. 2018. Post-Brexit EU/UK security cooperation: NATO, CSDP+, or "French connection"? British Journal of Politics and International Relations 20 (4): 846-863.

May, T. 2020. Nationalism is no ally in this battle without borders, The Times, 6 May. Retrieved April 30, 2021, from https://www.thetimes.co.uk/article/theresa-may-nationalism-is-no-ally-in-this-battlewithout-borders-m2sp37tvz?region=global\&ni-statuscode=acsaz-307.

May, E., and G. Treverton. 1986. Defence relationships: American perspectives. In The 'Special Relationship': Anglo-American Relations since 1945, ed. W. Louis and H. Bull. Oxford: Clarendon Press.

Mearsheimer, J. 2019. Bound to fail. John J. Mearsheimer. The rise and fall of the liberal international order. International Security 43 (4): 7-50.

Mitchell, A. 2018. Assistant Secretary A. Wess Mitchell, Bureau of European and Eurasian Affairs, Senate Foreign Relations Committee, Subcommittee on Europe and Regional Security Cooperation Hearing: U.S. Policy in Europe, 26 June. Retrieved October 30, 2021, from https://www.foreign. senate.gov/imo/media/doc/062618_Mitchell_Testimony.pdf.

Mills, C. 2019. Brexit and UK defence: An explainer, Briefing Paper, No. 8676, House of Commons Library. Retrieved January 2, 2021, from https://researchbriefings.files.parliament.uk/documents/ CBP-8676/CBP-8676.pdf.

Mills, C. and Smith, B. 2021. End of Brexit transition: Implications for defence and foreign policy cooperation, 19 January. Retrieved October 31, 2021, from https://researchbriefings.files.parliament.uk/ documents/CBP-9117/CBP-9117.pdf.

NCSC. 2019. Advisory: Turla group exploits Iranian APT to expand coverage of victims, 11 October. Retrieved June 7, 2020, from https:/www.ncsc.gov.uk/news/turla-group-exploits-iran-apt-toexpand-coverage-of-victims.

NCSC. 2020. NCSC supports US advisory regarding GRU intrusion set Sandworm, 28 May. Retrieved June 7, 2020, from https://www.ncsc.gov.uk/news/ncsc-supports-sandworm-advisory.

Nye, J. 2019. The rise and fall of American Hegemony from Wilson to Trump. International Affairs 95 (1): 63-80.

Pajon, C. 2018. A new Japan-France Strategic Partnership: A view from Paris. Lettre Du Centre Asie 74: 1-5.

Pew Research Centre. 2021. British, French and German publics give Biden high marks after U.S. Election, 19 January. Retrieved April 30, 2021, from https://www.pewresearch.org/global/2021/01/19/ british-french-and-german-publics-give-biden-high-marks-after-u-s-election/. 
Raab, D. 2020. Foreign Secretary's statement on Huawei, 28 January. Retrieved January 29, 2021, from https://www.gov.uk/government/speeches/foreign-secretary-statement-on-huawei.

Reiss, M. 2009. Introduction. In US-UK relations at the start of the 21 st century, ed. J. McCausland and D. Stuart, v-vii. New York: Nova Science Publishers.

Reynolds, D. 1986. A "Special Relationship"? America, Britain and the International order since the Second World War. International Affairs 62 (1): 1-20.

Reynolds, D. 2019. The end of the special relationship, The Wall Street Journal, 19 July. Retrieved December 21, 2021, from https://www.wsj.com/articles/the-end-of-the-special-relationship-11563 544911.

Sanders, E. 2006. Historical institutionalism. In The Oxford handbook of political institutions, ed. R. Rhodes, S. Binder, and B. Rockman. Oxford: Oxford University Press.

Shipman, T. 2020. Ben Wallace interview: We can't rely on US, The Times, 12 January. Retrieved January 14, 2021, from https://www.thetimes.co.uk/edition/news/ben-wallace-interview-we-cant-relyon-us-pmwcgv398.

Sillars, J. 2019. Boris Johnson "disappointed" as Trump aims tariffs at UK products, Sky News. 3 October. Retrieved May 1, 2021, from https://news.sky.com/story/boris-johnson-disappointed-as-trumpaims-tariffs-at-uk-products-11826292.

Stephens, P. 2021. Britain alone: The path from Suez to Brexit. London: Faber \& Faber.

Stokes, D. 2018. Trump, American Hegemony and the future of the liberal international order. International Affairs 94 (1): 133-150.

Summers, T. 2020. Better the devil you know? US-China strategic rivalry and the UK's China policy, in M. Esteban and M. Otero-lglesias (ed.) Europe in the Face of US-China Rivalry, pp. 171-178.

The Economist. 2021. Enter AUKUS. The new geopolitics of Asia, 25 September, 21-26.

The NSA. 2021a. NSA Cybersecurity 2020 Year in Review, 12 January. Retrieved October 31, 2021, from https://us-cert.cisa.gov/ncas/current-activity/2021/01/12/nsa-cybersecurity-directorate-relea ses-2020-year-review.

The NSA. 2021b. GCHQ and NSA celebrate 75 years of UKUSA agreement, 4 March. Retrieved May 2, 2021, from https://www.nsa.gov/News-Features/Feature-Stories/Article-View/Article/2524368/ gchq-and-nsa-celebrate-75-years-of-ukusa-agreement/.

The UK Government. 2015. Embedded arrangements between the UK and the US, 8 September. Retrieved December 8, 2019, from https://assets.publishing.service.gov.uk/government/uploads/ system/uploads/attachment_data/file/462737/20150908-FOI-Embed-Arrangements-UK-US-Annex7054.pdf.

The UK Government. 2020a. New dates agreed for COP26 United Nations Climate Change Conference, 28 May. Retrieved June 3, 2020, from https://www.gov.uk/government/news/new-dates-agreed-forcop26-united-nations-climate-change-conference.

The UK Government. 2020b. E3 statement on the JCPOA: 12 January 2020, 12 January. Retrieved January 14, 2020, from https://www.gov.uk/government/news/e3-statement-on-the-jcpoa-12-janua ry- 2020 .

The UK Government. 2020c. Huawei to be removed from UK 5G networks by 2027, 14 July. Retrieved January 14, 2020, from https://www.gov.uk/government/news/huawei-to-be-removed-from-uk-5gnetworks-by-2027.

The UK Government. 2021. 'Global Britain in a competitive age', The Integrated Review of Security, Defence, Development and Foreign Policy, March, The Stationery Office, London.

The US Congress. 2019. Senate resolution 137-Expressing the sense of the senate that the President should work with the government of the United Kingdom to prepare for a future free trade agreement between the United States and the United Kingdom, Congressional Record Vol. 165, No. 57, 2 April. Retrieved October 30, 2021, from https://www.congress.gov/congressional-record/2021/3/ 24/senate-section/article/s1776-1?q=\%7B $\% 22$ search $\% 22 \% 3 \mathrm{~A} \% 5 \mathrm{~B} \% 22$ the+United+Kingdom $\% 22 \%$ $2 \mathrm{C} \% 22$ the $\% 22 \% 2 \mathrm{C} \% 22$ United $\% 22 \% 2 \mathrm{C} \% 22 \mathrm{Kingdom} \% 22 \% 5 \mathrm{D} \% 7 \mathrm{D} \& \mathrm{~s}=1 \& \mathrm{r}=1$.

The US Congress. 2021a. 'Foreign Relations', Congressional Record Vol. 167, No. 164, 22 September. Retrieved October 30, 2021, from https://www.congress.gov/congressional-record/2021/9/22/senate-section/article/s6596-3?q=\%7B \% 22search $\% 22 \% 3 \mathrm{~A} \% 5 \mathrm{~B} \% 22$ United+Kingdom $\% 22 \% 2 \mathrm{C} \% 22$ Uni ted $\% 22 \% 2 \mathrm{C} \% 22$ Kingdom $\% 22 \% 5 \mathrm{D} \% 7 \mathrm{D} \& \mathrm{~s}=9 \& \mathrm{r}=5$.

The US Congress. 2021b. Expressing support for the full implementation of the good friday agreement, or the belfast agreement, and subsequent agreements and arrangements for implementation to support peace on the, Issue: Vol. 167, No. 85, 17 May. Retrieved October 30, 2021, from https://www. congress.gov/congressional-record/2021/5/17/senate-section/article/s2550-3?q=\%7B $\% 22$ search $\%$ 
$22 \% 3 \mathrm{~A} \% 5 \mathrm{~B} \% 22$ United+Kingdom $\% 22 \% 2 \mathrm{C} \% 22$ United $\% 22 \% 2 \mathrm{C} \% 22$ Kingdom $\% 22 \% 5 \mathrm{D} \% 7 \mathrm{D} \& \mathrm{~s}=$ $9 \& r=2$.

The US Congress. 2021c. S. Rept. 117-39 - National Defense Authorization Act for Fiscal Year 2022, 117th Congress (2021-2022). Retrieved October 31, 2021, from https://www.congress.gov/congr essional-report/117th-congress/senate-report/39.

The US Department of Defense. 2021. Statement on carrier strike group 2021 joint declaration signing, 19 January. Retrieved May 2, 2021, from https://thediplomat.com/2020/09/rise-of-the-minilateralsexamining-the-india-france-australia-trilateral/.

The US Department of State. 2019. A free and open Indo-Pacific: Advancing a shared vision, 4 November. Retrieved January 17, 2021, from https:/www.state.gov/a-free-and-open-indo-pacific-advan cing-a-shared-vision/.

The US Senate Committee on Foreign Relations. 2021. Risch, Johnson, Colleagues Introduce Iran Nuclear Treaty Act to Place Constitutional Check on Iran Deal, 11 June. Retrieved October 31, 2021, from https://www.foreign.senate.gov/press/ranking/release/risch-johnson-colleagues-intro duce-iran-nuclear-treaty-act-to-place-constitutional-check-on-iran-deal.

The White House. 2019. Remarks by President Trump and Prime Minister May in Joint Press Conference, 4 June. Retrieved December 19, 2019, from https://www.whitehouse.gov/briefings-statements/ remarks-president-trump-prime-minister-may-joint-press-conference/.

The White House. 2020. United States strategic approach to the People's Republic of China, 26 May. Retrieved June 3, 2020, from https://www.whitehouse.gov/articles/united-states-strategic-approachto-the-peoples-republic-of-china/.

The White House. 2021. Remarks by President Biden on America's place in the world, 4 February. Retrieved April 30, 2021, from https://www.whitehouse.gov/briefing-room/speeches-remarks/2021/ 02/04/remarks-by-president-biden-on-americas-place-in-the-world/.

Tsuruoka, M. 2018. A new Japan-France strategic partnership: A view from Tokyo, Lettre du Centre Asie, IFRI. No. 75: 1-6.

Wallace, W., and C. Phillips. 2009. Reassessing the special relationship. International Affairs 85 (2): 263-284.

Walt, S. 1997. Why alliances endure or collapse. Survival 39 (1): 156-179.

WHO. 2021. United Kingdom of Great Britain and Northern Ireland: Partner in global health. 28 April. Retrieved October 31, 2021, from https://www.who.int/about/funding/contributors/gbr.

Wilson, G. 2017. Brexit, Trump and the special relationship. The British Journal of Politics and International Relations 19 (3): 543-557.

Wintour, P. 2020. UK-US trade deal under threat unless Iran stance changes, says Trump ally, The Guardian, 15 January. Retrieved June 3, 2020, from https://www.theguardian.com/world/2020/jan/15/ boris-johnson-uk-us-trade-deal-under-threat-unless-iran-stance-changes-says-trump-ally.

Wright, T. 2019. How Trump undermined Theresa May, The Atlantic, 31 May. Retrieved December 25, 2019, from https://www.theatlantic.com/ideas/archive/2019/05/trump-undermines-uk-and-bulliestheresa-may/590758/.

Publisher's Note Springer Nature remains neutral with regard to jurisdictional claims in published maps and institutional affiliations. 